\title{
Enhancing Student Engagement in VLE Platform: Student Perceptions Towards Programming Course Learning Resources
}

\author{
Abu Hassan Darusman ${ }^{1}$, Yuhanis Omar ${ }^{2}$ \\ ${ }^{1}$ Universiti Kuala Lumpur, Malaysia France Institute \\ ${ }^{2}$ Universiti Kuala Lumpur, Malaysian Institute of Information Technology \\ 1abuhasan@unikl.edu.my, ${ }^{2}$ yuhanis@unikl.edu.my
}

\begin{abstract}
For many years, e-learning is one of the topics of interest among academia. The increase of wireless devices and smartphone usage as the current technology and platform to access internet services plays an important role in e-learning to be used in teaching and learning activities. Virtual Learning Environment (VLE) is a web-based system designed to facilitate e-learning with various elements in it. However, one of the biggest challenges in implementing e-learning with an efficient and effective learning resources component is the lack of motivation and student engagement in using it continuously. Therefore, the objective of this study is to obtain the students' perceptions as well as suggestions about learning resources in VLE that can be used to raise their level of motivation and engagement in the e-learning environment. This paper aims to discuss the findings of preliminary investigation related to the elements or characteristics of learning resources that can fulfill the need of the students in their studies at university. This study used a qualitative approach by interviewing a group of 60 students to; (1) obtain students' perceptions on the existing learning resources, (2) identify the issues or challenges in using the existing learning resources, and (3) record the suggestions that can be considered to improve the learning resources in VLE to make them motivated and engaged to the e-learning platform continuously. The results in a form of suggestions can be used as a guideline for academia to improve their learning resources.
\end{abstract}

Keywords

e-learning; VLE; motivation; engagement.

Article Received: 10 August 2020, Revised: 25 October 2020, Accepted: 18 November 2020

\section{Introduction}

The use of e-learning platforms in the teaching and learning process is not new. Almost all higher educational institutions implement e-learning facilitated with Virtual Learning Environment (VLE) to academia and students. With the development of computer technology, internet facilities, smartphone, and mobile devices, the e-learning environment is improved from time to time. The internet has flexibility, mobility, and convenience in information acquisition, storage, transmission, and sharing of information with others. This facility helps to overcome the limitation of space and time constraints of students and lecturers in the teaching and learning process. This is further compounded by educational technology that needs to change according to the current needs of students in line with the development of learning methods themselves. E-learning itself is defined as the development of knowledge and skills through the use of information and communication technology (ICT). Its function is to support interactions among those who use it for learning [1]. Such an environment allows individuals to learn new skills [2] without having physical lecturers or instructors who teach them in the face-to-face method. Because of the influence of the technology mentioned above, it becomes the center of attraction for academia to practice the online learning environment.

In the current growing COVID-19 outbreak, the use of elearning has dramatically increased as almost all higher education use this platform to replace the conventional way of learning. This is due to the closure of academic institutions and the disruption of on-campus classroom or laboratory activities. The reason for using this platform is not only because of the pandemic but also as a medium of self-learning by the students who are unable to attend lectures due to illness or certain personal reasons. Virtual Learning Environment (VLE) is one of the web-based systems that facilitate the e-learning platform. It consists of common features such as learning materials (course content tools), assessments, interactions, student work, management, and other tools. It has been reported that VLE is one of the effective and efficient learning platforms compared to the conventional face-to-face method [3], [4] where it gives benefits to both lecturers and students by having its easiness to be accessed anytime anywhere [5]. Students of higher education institutions of this century are very demanding of a more flexible learning structure. The need for this flexibility led to the need for clear alternative delivery methods using internet facilities and mobile devices.

The main aim of VLE is to facilitate and support the students with the enhanced learning experience. This can be achieved within the e-learning environment. A study by [3] shows that e-learning tool is one of the great motivations for university students. However, one of the biggest issues or challenges is the lack of motivation and student engagement towards using the VLE consistently especially for learning resources for their learning process. Learning resources might include videos, recordings, additional reading materials, software, skill-sharing platform, and textbooks. This is especially for the subjects that are related to practical sessions and programming courses. In the existing implementation, videos or PowerPoint slides are used as a medium to deliver their course contents. Unfortunately, based on the students' response, the slides provided by the instructors or lecturers are less attractive, less interactive, and "lifeless", or in a form of plain standard video without 
elements that can motivate the students to follow the learning session by using the existing course contents mediums. The need to update the learning resources is crucial because the students must be provided with the latest information and knowledge [6]. Furthermore, as for the programming subject is related to skill development which usually taught in the computer laboratory, the contents that are prepared in slides are not enough and sometimes are not so helpful for certain students.

Students' engagement is interpreted as a kind of psychological investment towards learning, understanding, or mastering the knowledge, skills, or crafts that meant to promote academic work [7]. This engagement is closely related to learning motivation. Learning motivation is defined as a condition that will activate learners' behaviour and gives specific direction [8] to them. Motivation could influence how students approaching their learning [9]. It is important in their academic achievement because higher motivation results in higher academic achievement [10].

Thus, the objectives of this study are to:

1) obtain students' perception of the existing learning resources,

2) identify the issues or challenges in using the existing learning resources, and

3) record the suggestions that can be considered to improve the learning resources in VLE to make them motivated and engaged in the e-learning platform continuously.

The contributions for this study are:

1) it triggers the use of gamification elements in the preparation of learning resources. The use of various techniques in the game elements will motivate students to engage with the VLE platform.

2) to suggest the use of a virtual reality environment in learning resources that involve many practical activities in the laboratory. This will help to decrease the boredom feelings when they need to do self-learning at home. It can be used repeatedly to assist the students in their self-directed learning process.

3) it becomes a guideline for academia to improve their learning materials by following the latest method and technology of delivering the course contents. At the same time, it will create various opportunities for student engagement in the online learning environment [7].

\section{Methodology}

Programming subjects are part of the courses that must be taken by information technology students. The purpose of offering programming courses such as Principles of Computer Programming that using Java, or $\mathrm{C \#}$ in Application Development subjects is to build logical thinking on solving a specific challenge, to provide abilities and technical skills in critical thinking, problem-solving, processing skills, determination, mathematical inclination, persistency, creativity, and innovation. Some students considered the programming courses are difficult. Therefore, sometimes it might affect the failure rates [11], [12] in such courses. This kind of perception may decrease students' motivation and can be a reason the student dropout [8] from their program. It has been found that if the workload in the programming class is too heavy compared with the students' level of experience [13], students more likely will change their program. Due to this condition, it inevitably has a huge impact on the performance of the students themselves. This study used a qualitative approach by interviewing a group of students from various programs who took programming courses and experts (lecturers who are teaching this subject).

\section{Participants}

The purpose of the interview sessions is to verify issues that occur during the teaching and learning process of programming courses and to obtain suggestions from students and lecturers about the improvement that should be made to the learning resources in the VLE platform. The study is based on the interview session with 60 students and 5 lecturers as the experts of the programming courses who teach C\#, Java, and PHP. The interviews with the students who enrolled for IEB20104 Application Development 1 (8 students), ISB10103 Principles of Computer Programming (23 students), and ISB42503 Internet Programming (29 students) were conducted after they have completed their course, particularly in Jan 2020 semester. These 5 experts were selected based on their experience in teaching the related programming courses.

\section{Interview Questions}

The following is Table 1 that contains the interview questions given to the particpants:

Table 1: Interview Questions

\begin{tabular}{|c|c|c|}
\hline $\mathbf{Q}$ & Question & Reference \\
\hline 1 & $\begin{array}{l}\text { What programming course(s) do you } \\
\text { register for this semester? }\end{array}$ & $\begin{array}{l}\text { Common } \\
\text { question }\end{array}$ \\
\hline 2 & $\begin{array}{l}\text { Do you have any prior experience in } \\
\text { programming courses? }\end{array}$ & $\begin{array}{l}\text { Common } \\
\text { question }\end{array}$ \\
\hline 3 & $\begin{array}{l}\text { Do you agree programming courses } \\
\text { are difficult? }\end{array}$ & $\begin{array}{ll}{[8],} & {[12],} \\
{[13]} & \end{array}$ \\
\hline 4 & $\begin{array}{l}\text { Do you agree that the difficulty of } \\
\text { programming courses will decrease } \\
\text { students' motivation? }\end{array}$ & [13] \\
\hline 5 & $\begin{array}{l}\text { Does prior experience in } \\
\text { programming influence students' } \\
\text { motivation? }\end{array}$ & {$[14]$} \\
\hline 6 & $\begin{array}{l}\text { Do you think that lack of motivation } \\
\text { will gives an impact on students' } \\
\text { disengagement in using VLE? }\end{array}$ & {$[15]$} \\
\hline 7 & $\begin{array}{l}\text { Do you agree that learning resources } \\
\text { are the central focus and play a } \\
\text { crucial role in stimulating the use of } \\
\text { VLE? }\end{array}$ & [7], [16] \\
\hline \multirow[t]{3}{*}{8} & $\begin{array}{l}\text { There are many issues and } \\
\text { challenges related to the lack of } \\
\text { motivation and loss of interest in } \\
\text { programming courses resulting from } \\
\text { the disengagement of the VLE } \\
\text { platform by the students. What do } \\
\text { you think the reason(s) behind it? }\end{array}$ & {$[15]$} \\
\hline & $\begin{array}{l}\text { A. No prior experience of } \\
\text { learning programming courses. }\end{array}$ & {$[14]$} \\
\hline & B. Learning resources (e.g., & [17] \\
\hline
\end{tabular}




\begin{tabular}{|c|c|c|}
\hline & $\begin{array}{l}\text { reading PowerPoint slides, watching } \\
\text { videos) are less interactive and } \\
\text { attractive. }\end{array}$ & \multirow[b]{2}{*}{ [18] } \\
\hline & $\begin{array}{l}\text { C. No gamification elements } \\
\text { in learning resources or activities are } \\
\text { adapted. }\end{array}$ & \\
\hline & $\begin{array}{l}\text { D. No virtual reality elements } \\
\text { in learning resources or activities are } \\
\text { adapted. }\end{array}$ & [19] \\
\hline & $\begin{array}{l}\text { E. Less interaction between } \\
\text { students and instructors or lecturers. }\end{array}$ & [7] \\
\hline \multirow[t]{6}{*}{9} & $\begin{array}{l}\text { In your opinion, which technique(s) } \\
\text { do you think could improve the } \\
\text { students, motivation and } \\
\text { engagement in using the VLE } \\
\text { platform for learning resources? }\end{array}$ & \multirow[t]{6}{*}{ [18] } \\
\hline & A. $\quad$ Gamification elements. & \\
\hline & Interactive visualizations. & \\
\hline & C. $\quad$ Virtual reality environment. & \\
\hline & $\begin{array}{l}\text { D. Learning notes (PowerPoint } \\
\text { slides, additional notes). }\end{array}$ & \\
\hline & E. $\quad$ Videos. & \\
\hline
\end{tabular}

\section{Results}

The data were collected and analyzed using the percentage and frequency method. The total number of participants is $\mathrm{N}$ $=60$, where female students are 37 and male students are 23 . The results are shown in Table 2 for common questions and Table 3 for specific survey results.

\section{Participants and programming courses}

Table 2: Common Questions

\begin{tabular}{|l|l|l|l|l|l|}
\hline Q & Item & \multicolumn{4}{|l|}{ Programming Courses } \\
\hline \multicolumn{2}{|c|}{} & $\begin{array}{l}\text { IEB2014 } \\
\text { AD 1 } \\
\text { (C\#) }\end{array}$ & $\begin{array}{l}\text { ISB10103 } \\
\text { PCP } \\
\text { (Java) }\end{array}$ & $\begin{array}{l}\text { ISB42503 } \\
\text { IP } \\
\text { (PHP) }\end{array}$ \\
\hline 1 & $\begin{array}{l}\text { Number } \\
\text { students }\end{array}$ & 8 & 23 & 29 \\
\hline \multicolumn{2}{|l|}{} & Yes & No \\
\hline 2 & $\begin{array}{l}\text { Prior } \\
\text { programming } \\
\text { experience }\end{array}$ & F & \% & F & \% \\
\cline { 3 - 6 } & 27 & 45.00 & 33 & 55.00 \\
\hline
\end{tabular}

Table 2 shows the results of the number of students who registered for the programming courses.

From the table:
Q : Question number
AD : Application Development 1
PCP : Principles of Computer Programming
IP : Internet Programming
F : Frequency

Based on the results, $45.00 \%$ of the students have prior experience in programming courses while $55.00 \%$ do not have any experience in programming languages. This is because 27 students are from diploma level and they have learned Java and PHP in their previous universities during their diploma level of study.

\section{Students perceptions based on the interview session}

Table 3: Survey Results

\begin{tabular}{|c|c|c|}
\hline Item & $\mathbf{F}$ & $\%$ \\
\hline $\begin{array}{llll}1 . & \text { Programming } & \text { courses } & \text { are } \\
\text { difficult. } & & & \\
\end{array}$ & 49 & 82.67 \\
\hline $\begin{array}{l}2 . \quad \text { Difficulty decrease students' } \\
\text { motivation. }\end{array}$ & 53 & 88.33 \\
\hline $\begin{array}{l}\text { 3. Prior experience influence } \\
\text { students' motivation. }\end{array}$ & 45 & 75.00 \\
\hline $\begin{array}{l}\text { 4. Lack of motivation gives impact } \\
\text { to disengagement in using the VLE. }\end{array}$ & 56 & 93.33 \\
\hline $\begin{array}{l}5 . \quad \text { Learning resources are the } \\
\text { central focus and play an important role in } \\
\text { stimulating the use of the VLE. }\end{array}$ & 60 & 100.00 \\
\hline $\begin{array}{l}6 . \quad \text { Reason(s) of disengagement to } \\
\text { the VLE platform. }\end{array}$ & & \\
\hline $\begin{array}{l}\text { A } \quad \begin{array}{l}\text { No prior experience of learning } \\
\text { programming courses. }\end{array} \\
\end{array}$ & 47 & 78.33 \\
\hline $\begin{array}{lcr}\text { Learning } & \text { resources } & \text { (e.g., } \\
\text { reading PowerPoint } & \text { slides, } \\
\text { watching videos) are less } \\
\text { interactive and attractive. }\end{array}$ & 60 & 100.00 \\
\hline $\begin{array}{l}\text { No gamification elements in } \\
\text { learning resources or activities } \\
\text { are adapted. }\end{array}$ & 58 & 96.67 \\
\hline $\begin{array}{l}\text { No virtual reality elements in } \\
\text { learning resources or activities } \\
\text { are adapted. }\end{array}$ & 56 & 93.33 \\
\hline $\begin{array}{lll}\text { E Less interaction between } \\
\text { students and instructors or } \\
\text { lecturers. }\end{array}$ & 53 & 88.33 \\
\hline \multicolumn{3}{|l|}{$\begin{array}{l}7 . \quad \text { The technique(s) to improve } \\
\text { students' motivation and engagement in } \\
\text { using the VLE platform. }\end{array}$} \\
\hline A $\quad$ Gamification elements. & 60 & 100.00 \\
\hline Interactive visualizations. & 60 & 100.00 \\
\hline Virtual reality environment. & 60 & 100.00 \\
\hline $\begin{array}{l}\text { Learning notes (PowerPoint } \\
\text { slides, additional notes). }\end{array}$ & 29 & 48.33 \\
\hline Videos. & 33 & 55.00 \\
\hline
\end{tabular}

From Table 3 above, we can conclude that learning resources are one of the vital parts of the VLE that must be given more attention. This can be proven by looking at the response given by the students in item number 5. All students agreed that learning resources are the central focus of why they use VLE. This is because learning resources in the VLE are the main source where they can get knowledge and information that is related to what they have learned from their lecturers. Furthermore, they will always refer to these learning resources whenever they face problems in writing programs. As a result, it can stimulate them to engage in the VLE. This can be added with the feedback of $82.67 \%$ of students saying that the programming courses are difficult for them and they need to put high effort into understanding the concept and do the practical part. During this movement control order (MCO) due to the pandemic, it increases their stressfulness of learning programming courses because they have less interaction with their lecturers and need to solve the problem alone at home. 
Besides, they cannot rely on their friends who have prior knowledge of programming concepts as they too might face certain problems in other courses. $75.00 \%$ agreed that prior experience in programming courses will influence students' motivation. In that case, $88.33 \%$ agreed that this difficulty will decrease the motivation of learning the programming course. This brings to the result of disengagement in using the VLE where $93.33 \%$ agreed that the reason is because of the lack of motivation.

On the question that requires the students to respond about the reason(s) behind the lack of motivation and loss of interest in programming courses, all of them (100.00\%) agreed that less interactive and less attractive learning resources where they just read the PowerPoint slides or watching videos are the main challenge to attend lectures conducted by the lecturers via online mode, to create interest in this course and to have the motivation to continuously use the learning resources in the VLE. This resulting in the disengagement of the students with the course contents uploaded in the VLE. $96.67 \%$ and $93.33 \%$ agreed that there is no advanced technology such as gamification or virtual reality implemented or adapted in the learning resources are also part of the reasons they were less interested in having the motivation to the programming courses. The less interaction between them and their lecturers brings the output of $88.33 \%$ to the reasons. Although the results show that $78.33 \%$ of no prior experience of learning programming courses, but based on their feedback, they believe that it cannot be the main reason for not learning the course or drop out of the course.

When asking about their opinion about the technique(s) that can be used to be adapted in learning resources preparation, all of them agreed that gamification elements, interactive visualizations, and virtual reality (VR) environment could bring big impact to them and definitely will motivate them in using and engage to the VLE, especially for the learning resources. $48.33 \%$ and $55 \%$ respectively agreed that learning notes such as PowerPoint slides, additional notes, and videos can remain.

\section{Interview with experts}

Apart from the interview with students, another informal interview session has been done with 5 lecturers who teach programming courses. These qualified experts have experience of not less than 8 years in teaching programming subjects. The purpose of interviewing the lecturers is to have a check and balance with the students' opinions and to obtain concrete ideas in overcoming problems of lack of motivation and disengagement to the VLE platform for learning resources. Above all questions, they were asked about the main challenge or issues in teaching this course and the reasons why students feel a lack of motivation and disengage from using the VLE for the learning resources. Moreover, it is important to investigate and to know what kind of technology can be used to solve the problems or issues.

The experts reacted positively to the gamification elements suggested by the interviewed students. The experts suggested that the gamification concepts will be more interesting if the learning resources can be connected to the assessment part of the course. It will create a new form of assessing the students wherefrom the gamification elements, they can create the assignment questions based on the level of assessment in the course learning plan, the marks which is in a form of reward the students collected from the game (assessment) level, competition and collaboration among students in the game for their group project, progress bar to show the progress of their learning and assessment completion, level, scoreboard and feedback from the lecturers who teach and monitor them in programming course. In this case, the student profile must be visible to show the progress and achievements in terms of the understanding of the course, assessment, and creating motivation in them. The value of competency in this gamification concept will engage the students to the VLE platform.

As for the suggestion of using a VR environment, the experts gave a good reaction to it, but they suggested giving a certain time because the development of the VR environment itself also involves many phases and needs a certain duration of time. It is indeed interesting to use the VR concept, but the detail and precision of every single topic in the course must be given specific attention. The experts also agreed that VR can enhance student engagement in using the VLE platform for learning resources and at the same time motivate the students to learn the course that they considered as a difficult subject.

On the other hand, the experts disagreed with the opinion of less interaction between students and lecturers because, in the VLE itself, there is a feature of online discussion. This is one of the important tools that can be used by the students to actively participate in discussions with their peers and lecturers, and increase their understanding of programming. In regards to learning resources, the experts also agreed on using as many types of multimedia elements to attract and create interest of the students to follow the course if they still want to maintain the use of PowerPoint slides for their lecture notes. This can overcome the boredom feelings among students.

\section{Conclusion}

Looking back from the previous experience, only students who have a high interest in programming courses will use their initiative to give extra effort in searching for additional learning resources for them to learn this course on their own. Therefore, the lecturers who teach programming courses cannot only maintain or rely on their existing PowerPoint slides, videos that they downloaded from YouTube, noninteractive videos with fewer visualizations and etcetera. The issues of lack of motivation, disengagement to elearning platform is not only on the VLE, but it also gives a big impact to web-based platform and m-learning. As well as the concept of gamification that can be adapted in learning resources, previous research has shown that it still has a certain problem as not all institutions provide game elements to be integrated into the learning platform. To have effective learning resources, thorough research must be done so that only adequate elements can be adapted in gamification or virtual reality concepts in learning resources.

The survey has proven that action must be taken by academia to improve learning resources. No matter the 
delivery of the contents is online or conventional face-toface, it cannot be denied that the motivational part in the learning process is very important. This is to ensure the students understand the knowledge they will obtain from the course, participate and engage with the platform provided for them. Academia must take certain actions to move in line with the development of existing technologies to further streamline the process of teaching and learning..

\section{References}

[1] A. M. Tirziu, and C. Vrabie "Education 2.0: e-learning methods," IEEE Procedia Social and Behavioral Sciences, 186(2015), pp. 376-380, 2015.

[2] P. Abrami, R. Bernard, A. Wade, E. Borokhovski, R. Tamin, M. Surkes, and D. Zhang, D. "A review of e-learning in Canada: Rejoinder to commentaries," Canadian Journal of Learning and Technology, 32(3), p. 30, 2008.

[3] G. Harriman, "E-Learning resources," http://www.grayharriman.com/, 2014.

[4] JISC, 2008 online Innovating e-Learning online conference 2000. Learning in a Digital Age - Are we prepared?. [online]. From: http://www.jisc.ac.uk/elpconference08

[5] Moore, P. (2011). Anytime-Anywhere: Personalised Time in Networking for eLearning. eLC Research Paper Series, 3, 48-59

[6] M. A. Alsubhi, N. Sahari, T.S.M.T. Wook, "The challenge of increasing student engagement in e-learning platform," IEEE Electrical Engineering and Informatics, 978-1-7281-2418-6/19, 2019

[7] F. Martin and D. U., Bolliger, "Engagement Matters:Student Perceptions on the Importance of Engagement Strategies in the Online Learning Environment," Online Learning Journal Volume 22 Issue 1 - March, 2018

[8] K. Kori, M. Pedaste, and E. Tonisson, "The Role of Programming Experience in ICT Students'Learning Motivation and Academic Achievement," International Journal of Information and Education Technology, Vol. 6, No. 5, May 2016.
[9] N. Entwistle, "Concepts and conceptual frameworks underpinning the ETL project," Occasional Report 3, Edinburgh, Scotland: ETL Project, 2003.

[10] M. Bruinsma, "Motivation, cognitive processing and achievement in higher education," Learning and Instruction, vol. 14, no. 6, pp. 549-568, 2004.

[11] J. Bennedsen and M. E. Caspersen, "Failure rates in introductory programming," The SIGCSE Bulletin, vol. 39, no. 2, pp. 32-36, 2007.

[12] I. Miliszewska and G. Tan, "Befriending computer programming: A proposed approach to teaching introductory programming," Informing Science and Information Technology, vol. 4, pp. 277289, 2007.

[13] L. J. Baker, C. McDowell, and K. Kalahar, "Exploring factors that influence computer science introductory course students to persist in the major," in Proc. the 40th ACM Technical Symposium on Computer Science Education, pp. 153-157, 2009.

[14] K. Kori, M. Pedaste et al., "Why do students choose to study information and communications technology?" The European Procedia Social and Behavioral Sciences, Elsevier, 2014.

[15] K. M. Kapp, The gamification of learning and instruction: game-basedmethods and strategies for training and education. John Wiley \& Sons, 2012.

[16] J. Banna, M. F. G., Lin, M., Stewart, and M. K. J., Fialkowski, "Interaction matters: Strategies to promote engaged learning in an online introductory nutrition course," Journal of Online Learning and Teaching, 11(2), 249-261, 2015.

[17] J. Simões, R. D. Redondo, and A. F. Vilas, "A social gamification framework for a K6 learning platform," Computers in Human Behavior, vol. 29, no. 2, pp. 345-353, 2013.

[18] F. L. Khaleel, T. Wook, T. S. Meriam, and and A. Ismail, "Gamification elements for learning applications," International Journal on Advanced Science, Engineering 
and Information Technology, vol. 6, no. 6, pp. 868-874, 2016.

[19] P. Zhigeng, D. C. Adrian, Y. Hongwei, Z. Jiejie, and S. Jiaoying, "Virtual reality and mixed reality in virtual learning environments," Science Direct, Computer and Graphics, February, 2006. 